\title{
Monitoring of Floristic Composition and Species Diversity an Initial Step Towards the Restoration of Mangrove Forest in Teluk Adang Nature Reserve, Indonesia
}

\author{
Mukhlisi Mukhlisi ${ }^{1 *}$, Ahmad Nuryani², Tri Sayektiningsih ${ }^{3}$ \\ ${ }^{1}$ Research and Development Institute for Natural Resources Conservation Technology (Balitek KSDA), \\ Jl. Soekarno Hatta Km 38 Samboja PO BOX 578 Balikpapan 76112, Indonesia \\ ${ }^{2}$ Natural Resources Conservation Agency of East Kalimantan (BKSDA Kalimantan Timur), \\ Jl. Teuku Umar No 17 Sungai Kunjang, Samarinda, Indonesia \\ ${ }^{3}$ Environment and Forestry Research Institute of Makassar, \\ Jl. Perintis Kemerdekaan Km 16, Makassar 90242, Indonesia
}

Received: 19 March 2020

Accepted: 5 June 2020

\begin{abstract}
Mangrove is known as a unique and complex ecosystem, located in the intertidal zone vulnerable to anthropogenic pressures. In this study, we analyzed the floristic composition and relationship between species density and soil properties of mangrove forests in Teluk Adang Nature Reserve (TANR), East Kalimantan, Indonesia. Data were collected by establishing 6 transects placed perpendicular to the sea. The results showed that there were 14 species of mangroves in TANR. The current remaining stand has not been disturbed by human intervention. Rhizophora apiculata dominated all growth strata (seedlings, saplings, and trees) with the Important Value Index (IVI) of 98.22\%; 127.73\%, 144.03\%, respectively. Ecologically, the density and distribution of Rhizophora apiculata correlated with soil texture conditions such as silt and clay. The tree density of mangroves in TANR was classified as low with an average of $606.67 \pm 147.230$ ind $^{-1} \mathrm{a}^{-1}$. The average values of diameter, height, and basal area were $18.16 \pm 2.119 \mathrm{~cm} ; 12.24 \pm 2.667 \mathrm{~m} ; 42.56 \pm 2.255 \mathrm{~m} \mathrm{ha}^{-1}$, respectively. The Margalef species richness index and Shannon Wienner diversity index in TANR were in the low-to-moderate category. To improve the condition of the disturbed mangrove forests, it should be immediately restored by considering the result of the analysis of the current composition and structure of mangrove vegetation.
\end{abstract}

Keywords: Conservation, diversity, mangrove communities, Teluk Adang Nature Reserve

*e-mail: mukhlisi.arkan@gmail.com 


\section{Introduction}

Mangrove forests consist of plant communities tolerant of salinity and tides [1-3]. As the largest archipelagic country in the world, mangrove forests are widely distributed across Indonesia. Giri et al. [4] reported that Indonesia has around 3.1 million ha of mangrove forests or equivalent to $23 \%$ of the total area of mangrove forests in the world. Important distribution areas of mangroves in Indonesia are Kalimantan (Indonesian Borneo), Sumatra, and Papua [2]. To date, a total of 45 species of true mangroves have been identified from various regions in Indonesia [5]. Unfortunately, many areas of mangrove forests in this country are under pressure due to logging, conversion to fish ponds, and settlements $[2,6]$, resulting in a massive decline.

Teluk Adang Nature Reserve (TANR) is one of the important mangrove distribution areas on the coast of East Kalimantan. Uniquely, mangroves located in TANR are surrounded by several types of ecosystems such as swamp forests, heat forests, and tropical lowland forests. The mangrove forests in TANR are also an important habitat for various species of protected wildlife, such as estuarine crocodiles (Crocodylus porosus) and proboscis monkeys (Nasalis larvatus) which are endemic to Borneo Island [7]. Like other Indonesia's mangrove forests, mangroves in TANR also experienced a decline in quality because of considerable anthropogenic pressures. Firman et al. [8] reported that threats to mangrove forests in TANR are mainly because of ponds, settlements, and plantations. Based on spatial analysis, the total area of TANR's mangroves was $59,665.78 \mathrm{ha}$, and around $75 \%$ of them were disturbed and classified as the rehabilitation zone [9].

Mangrove forests are not only complex ecosystems and have high productivity, but are also known as a fragile ecosystem. A series of depletion of mangrove forests in TANR will reduce environmental services generated from the mangrove itself. As a conservation area, this is one of serious problems should be anticipated immediately. Studies related to the mangrove forests status, especially in terms of mangrove ecology, are still very limited in TANR. Previous studies discussed the importance of collaboration in managing mangroves of TANR [8]. Furthermore, a study conducted by the BKSDA Kaltim [9] reported that 6 species of mangrove composition were identified. However, further studies on the current condition of mangroves in TANR have never been carried out in detail. Understanding the composition and diversity of mangroves are very useful for determining the initial steps in restoration efforts $[10,11]$. It is also important to know the dynamics of changes in mangrove forest ecosystems [12], and the determination of the remaining mangrove forest protection zones.

To manage TANR better, data and information on the current ecological status of mangrove forests are needed. Therefore, this study aimed to analyze the floristic composition and relationship between species density and soil properties of mangrove forests in TANR. We expect the results to be one of reference policies of TANR area management.

\section{Experimental}

\section{Study Area}

This study was conducted in September 2019 in TANR mangrove forests, Paser District, East Kalimantan Province. The total area of TANR is $59,665.78$ ha. The mangrove forests in TANR are situated in a bay on the east coast of Borneo Island, facing the Makassar Strait. It is also surrounded by swamp forests, heat forests, and also tropical lowland forests. Soils are typified by low $\mathrm{pH}$ and high organic contents (Table 1).

Table 1. Soil properties of each transect in TANR, each value is expressed as mean \pm standard deviation (SD).

\begin{tabular}{|c|c|c|c|c|c|c|c|c|c|c|c|}
\hline \multirow{2}{*}{$\mathrm{T}$} & \multirow{2}{*}{$\begin{array}{c}\mathrm{pH} \\
\left(\mathrm{H}_{2} \mathrm{O}\right)\end{array}$} & \multicolumn{3}{|c|}{ Organic matters (\%) } & \multicolumn{4}{|c|}{ Cation Exchange (meq/100gr) } & \multirow{2}{*}{$\begin{array}{l}\text { CEC } \\
(\%)\end{array}$} & \multirow{2}{*}{ Sat $(\%)$} & \multirow{2}{*}{ Texture } \\
\hline & & $\mathrm{N}$ & $\mathrm{C}$ & $\mathrm{C} / \mathrm{N}$ & $\mathrm{Ca}^{++}$ & $\mathrm{Mg}^{++}$ & $\mathrm{Na}^{+}$ & $\mathrm{K}^{+}$ & & & \\
\hline $\mathrm{T} 1$ & $\begin{array}{c}5.23 \\
\pm 0.163\end{array}$ & $\begin{array}{c}0.47 \\
\pm 0.085\end{array}$ & $\begin{array}{c}5.08 \\
\pm 0.255\end{array}$ & $\begin{array}{c}10.95 \\
\pm 1.485\end{array}$ & $\begin{array}{c}4.62 \\
\pm 0.049\end{array}$ & $\begin{array}{c}7.36 \\
\pm 0.106\end{array}$ & $\begin{array}{c}78.41 \\
\pm 0.318\end{array}$ & $\begin{array}{c}1.38 \\
\pm 0.021\end{array}$ & $\begin{array}{c}92.92 \\
\pm 0.0474\end{array}$ & $\begin{array}{c}98.75 \\
\pm 0.247\end{array}$ & SCL \\
\hline $\mathrm{T} 2$ & $\begin{array}{c}5.00 \\
\pm 0.170\end{array}$ & $\begin{array}{c}0.43 \\
\pm 0.071\end{array}$ & $\begin{array}{c}4.82 \\
\pm 0.113\end{array}$ & $\begin{array}{c}11.46 \\
\pm 1.640\end{array}$ & $\begin{array}{c}4.91 \\
\pm 0.226\end{array}$ & $\begin{array}{c}7.64 \\
\pm 0.042\end{array}$ & $\begin{array}{c}75.87 \\
\pm 0.099\end{array}$ & $\begin{array}{c}1.40 \\
\pm 0.028\end{array}$ & $\begin{array}{c}92.48 \\
\pm 0.071\end{array}$ & $\begin{array}{c}97.12 \\
\pm 0.509\end{array}$ & SCL \\
\hline $\mathrm{T} 3$ & $\begin{array}{c}5.51 \\
\pm 0.184 \\
\end{array}$ & $\begin{array}{c}0.35 \\
\pm 0.014 \\
\end{array}$ & $\begin{array}{c}5.53 \\
\pm 0.141 \\
\end{array}$ & $\begin{array}{c}15.68 \\
\pm 0.318 \\
\end{array}$ & $\begin{array}{c}5.61 \\
\pm 1.075 \\
\end{array}$ & $\begin{array}{c}7.87 \\
\pm 0.078 \\
\end{array}$ & $\begin{array}{c}76.99 \\
\pm 9.058 \\
\end{array}$ & $\begin{array}{c}1.39 \\
\pm 0.035 \\
\end{array}$ & $\begin{array}{c}93.52 \\
\pm 8.026 \\
\end{array}$ & $\begin{array}{c}98.21 \\
\pm 0.156 \\
\end{array}$ & SCL \\
\hline $\mathrm{T} 4$ & $\begin{array}{c}5.28 \\
\pm 0.205\end{array}$ & $\begin{array}{c}0.41 \\
\pm 0.134\end{array}$ & $\begin{array}{c}4.91 \\
\pm 0.233\end{array}$ & $\begin{array}{c}12.99 \\
\pm 4.929\end{array}$ & $\begin{array}{c}4.26 \\
\pm 0.325\end{array}$ & $\begin{array}{c}7.01 \\
\pm 0.198\end{array}$ & $\begin{array}{c}70.66 \\
\pm 1.372\end{array}$ & $\begin{array}{c}1.35 \\
\pm 0.001\end{array}$ & $\begin{array}{c}84.62 \\
\pm 0.955\end{array}$ & $\begin{array}{c}98.42 \\
\pm 1.131\end{array}$ & SCL \\
\hline T5 & $\begin{array}{c}7.20 \\
\pm 0.071\end{array}$ & $\begin{array}{c}0.14 \\
\pm 0.092\end{array}$ & $\begin{array}{c}3.09 \\
\pm 2.100\end{array}$ & $\begin{array}{c}19.29 \\
\pm 4.476\end{array}$ & $\begin{array}{c}4.60 \\
\pm 0.021\end{array}$ & $\begin{array}{c}3.69 \\
\pm 2.949\end{array}$ & $\begin{array}{c}30.94 \\
\pm 31.007\end{array}$ & $\begin{array}{c}0.86 \\
\pm 0.339\end{array}$ & $\begin{array}{c}41.21 \\
\pm 33.955\end{array}$ & $\begin{array}{c}97.39 \\
\pm 2.143\end{array}$ & Sand \\
\hline T6 & $\begin{array}{c}7.33 \\
\pm 0.382\end{array}$ & $\begin{array}{c}0.16 \\
\pm 0.127\end{array}$ & $\begin{array}{c}3.10 \\
\pm 2.079\end{array}$ & $\begin{array}{c}20.29 \\
\pm 3.062\end{array}$ & $\begin{array}{c}4.62 \\
\pm 0.014\end{array}$ & $\begin{array}{c}3.73 \\
\pm 2.892\end{array}$ & $\begin{array}{c}31.94 \\
\pm 29.592\end{array}$ & $\begin{array}{c}0.96 \\
\pm 0.048\end{array}$ & $\begin{array}{c}41.91 \\
\pm 32.972\end{array}$ & $\begin{array}{c}97.70 \\
\pm 1.817\end{array}$ & Sand \\
\hline
\end{tabular}

Remarks: $\mathrm{T}=$ transect; $\mathrm{Sat}=$ saturation; $\mathrm{SCL}=$ sandy clay loam 


\section{Data Collection}

Six mangrove observation transects were made purposively. Each transect was placed perpendicular to the shoreline with the length adjusting the thickness of the mangroves [13]. We made 33 plots with a size of $20 \times 20 \mathrm{~m}$ or equivalent to $1.32 \mathrm{Ha}$ in total. At each transect, we established $2 \times 2 \mathrm{~m}$ observation subplots for seedlings (plant height $\leq 1.5 \mathrm{~m}$ ), $5 \times 5 \mathrm{~m}$ for saplings (plant height $>1.5 \mathrm{~m}$ and diameter $<10 \mathrm{~cm}$ ), and $20 \mathrm{x}$ $20 \mathrm{~m}$ for trees (plants with diameter $\geq 10 \mathrm{~cm}$ ) [14]. We collected $\pm 2000 \mathrm{~g}$ soil samples from each transect at a depth of 0-30 $\mathrm{cm}$ using a pipe tool. All species of mangroves were identified by scientific name, number of stand, stem diameter, and height. To obtain more comprehensive information on the composition of mangrove species, we observed outside the transect area to record other mangrove species. For each unidentified species, we collected herbarium specimen for further identification at Wanariset Herbarium (WAN) - Balitek KSDA (Balai Penelitian dan Pengembangan Teknologi Konservasi Sumber Daya Alam). Soil samples were further analyzed to determine their physical and chemical properties in the laboratory of the Center for Environmental and Natural Resources Research Mulawarman University, Samarinda.

\section{Data Analysis}

Vegetation data were analyzed by calculating the Importance Value Index (IVI) [13, 15]. IVI in seedling strata was obtained by adding up the values of relative density and relative frequency. Meanwhile, the IVI for saplings and trees was the sum of relative density, relative frequency, and relative dominance, which were calculated using the following equations: Relative density $=($ Density of the species/Total density of all species $) \times 100$. Relative frequency $=($ Frequency of the species/Total frequency of all species $) \times 100$. Relative dominance $=($ Basal area of the species/Total basal area of all species) $\times 100$. Vegetation analysis was also carried out by calculating the Margalef species richness index (R) [13], Shannon-Wienner species diversity index $\left(\mathrm{H}^{\prime}\right)[13,18]$, and dominance index (D) [18]:

$$
\mathrm{R}=(\mathrm{S}-1) / \ln (\mathrm{N})
$$

...where: $\mathrm{R}=$ Margalef species richness index; $\mathrm{S}=$ number of species in the community; $\mathrm{N}=$ number of individuals

$$
\mathrm{H}^{\prime}=-\sum_{i=1}^{s} \mathrm{Pi} \ln \mathrm{Pi}
$$

...where: $H^{\prime}=$ Shannon Wienner diversity index; $\mathrm{S}=$ number of species in the community; $\mathrm{pi}=$ proportion of the population made up of species $i$

$$
\mathrm{D}=\sum_{i=1}^{s} \mathrm{Pi}^{2}
$$

...where: $\mathrm{D}=$ Dominance index; $\mathrm{S}=$ number of species in the community; $\mathrm{Pi}=$ proportion of the population made up of species $i$.

Resemblance between transects was analyzed using Bray-Curtis similarity index [16] . To test differences of ecological index parameter among transects, we used the Kruskal Wallis test [17]. The test was applied since data did not meet the normality assumption and transformations were failed. Furthermore, a Canonical Correspondence Analysis (CCA) analysis was carried out to determine the characteristics of the mangrove forests for each transect based on soil conditions and its correlation with the density of the species. All calculations of each ecological index value and the statistical test were run using PAST. 3 [18].

\section{Results and Discussion}

\section{Species Composition}

Rhizoporaceae was the richest family (5 species), followed by Combretaceae (3 species), Arecaceae (2 species), and other families in which each family was represented by one species. Rhizophora apiculata and Bruguiera parviflora had the most extensive distribution because they occurred in all observed transects (Table 2). Most mangrove species identified were classified as major mangroves (9 species). Several other species were grouped into minor mangroves ( 2 species) and mangrove associates ( 3 species).

Indonesia is a tropical archipelago country and one of the most important distribution areas of mangroves in the world. According to Spalding et al. [5], there were 45 species of mangroves identified in this country. This makes Indonesia as the richest country in terms of mangrove species worldwide [2,5]. In this study, we only recorded 14 species of mangroves in TANR. However, number of species collected in this study was higher than that collected by TNAR's staff ( 6 species) [9]. Several new species recorded were A. marina, $S$. alba, B. parviflora, X. granatum, A. aureum, $N$. fruticans (major mangrove), and P. tectorius, T. catappa, $O$. tigillarium (mangrove associates). Previous studies conducted in other parts of Borneo Island, such as in the Semporna, Sabah (Malaysia) [19] and Kutai National Park (Indonesia) found a similar species composition [20]. Geographically, TANR is a bay directly facing the Makassar Strait. East Kalimantan coastal area, which is bordered by the Makassar Strait, is an important distribution of mangroves in the Indo West Pacific region [21]. The composition of mangrove species around the area was a result of geological adaptation over a thousand years. Therefore, the mangroves in the study site had higher species number [21]. 
Table 2. Mangrove species in TANR.

\begin{tabular}{|c|c|c|c|c|c|c|c|c|c|}
\hline \multirow{2}{*}{ No } & \multirow{2}{*}{ Family } & \multirow{2}{*}{ Species } & \multirow{2}{*}{$\begin{array}{l}\text { Mangrove } \\
\text { Group }\end{array}$} & \multicolumn{6}{|c|}{ Transect (T) } \\
\hline & & & & 1 & 2 & 3 & 4 & 5 & 6 \\
\hline 1 & Acantacheae & Avicennia marina (Forsk.) Vierh. & Maj & & & & & $\sqrt{ }$ & $\sqrt{ }$ \\
\hline 2 & Arecaeace & Nypa fruticans Wurmb & Maj & & & & & & $\sqrt{ }$ \\
\hline 3 & Arecaceae & Oncosperma tigillarium (Jack) Ridl.* & Ass & & & & & & \\
\hline 4 & Combretaceae & Sonneratia alba J.E.Smith & Maj & & & & & & $\sqrt{ }$ \\
\hline 5 & Combretaceae & Lumnitzera littorea (Jack) Voight* & Maj & & & & & & \\
\hline 6 & Combretaceae & Terminalia catappa* & Ass & & & & & & \\
\hline 7 & Meliaceae & Xylocarpus granatum Koening & Min & & & $\sqrt{ }$ & & & \\
\hline 8 & Pandanaceae & Pandanus tectorius Parkinson Ex Zucc* & Ass & & & & & & \\
\hline 9 & Pteridaceae & Acrostichum aureum $\mathrm{L}$. & Min & $\sqrt{ }$ & & & & & \\
\hline 10 & Rhizophoraceae & Rhizophora mucronata Lam. & Maj & $\sqrt{ }$ & $\sqrt{ }$ & & & & $\sqrt{ }$ \\
\hline 11 & Rhizophoraceae & Rhizophora apiculata Blume & Maj & $\sqrt{ }$ & $\sqrt{ }$ & $\sqrt{ }$ & $\sqrt{ }$ & $\sqrt{ }$ & $\sqrt{ }$ \\
\hline 12 & Rhizophoraceae & Bruguiera parviflora Wight \& Arn. & Maj & $\sqrt{ }$ & $\sqrt{ }$ & $\sqrt{ }$ & $\sqrt{ }$ & $\sqrt{ }$ & $\sqrt{ }$ \\
\hline 13 & Rhizophoraceae & Ceriops tagal (Perr.) C.B.Rob. & Maj & $\sqrt{ }$ & $\sqrt{ }$ & $\sqrt{ }$ & & & \\
\hline 14 & Rhizophoraceae & Ceriops decandra (Griff.) Ding Hou* & Maj & & & & & & \\
\hline
\end{tabular}

Remarks: Maj = major mangrove; Min = minor mangrove; Asso = Mangrove association;

*) = Mangrove species recorded outside the transect

None of the mangrove species recorded in this study is protected based on regulations in Indonesia. According to the IUCN Red List, we only found one mangrove species with Near Threatened (NT) category, C. decandra. Naturally, $C$. decandra has slow reproduction rate and is vulnerable to extreme environment [22]. C. decandra in TANR inhabits the back zone of mangrove forests. Remaining stand is also found around dikes. The low population of $C$. decandra is not only due to reproductive factors but also because their habitat is threatened by the expansion of ponds particularly in the transition area between mangrove and terrestrial ecosystems. Fish farmers in TNAR usually build their ponds with the distance 100-200 $\mathrm{m}$ from the sea. Consequently, species grown within that distance will be well developed in comparison to species inhabited the back mangrove and transitional zone. A similar phenomenon also occurs in L. littorea, which occupies habitats bordering terrestrial ecosystem. We only recorded two individuals of $L$. littorea during fieldwork. The main threat to L. littorea is logging since this species produces high quality wood [23]. Severe and continuous anthropogenic pressures are a cause for local extinction of several mangrove species in TANR, resulting in changes in species composition.

\section{Vegetation Structure}

The mean tree density of mangrove forests in TANR was $606.67 \pm 147.230$ ind ha $^{-1}$ (Table 3). The

Table 3. Density, diameter, height, and basal area of individual trees in TANR, each value is expressed as mean \pm standard deviation (SD).

\begin{tabular}{|c|c|c|c|c|}
\hline Transect & $\begin{array}{c}\text { Density } \\
\left(\text { ind ha }^{-1}\right)\end{array}$ & $\begin{array}{c}\text { Diameter } \\
(\mathrm{cm})\end{array}$ & $\begin{array}{c}\text { Height } \\
(\mathrm{m})\end{array}$ & $\begin{array}{c}\text { Basal Area } \\
\left(\mathrm{m}^{2} \mathrm{ha}^{-1}\right)\end{array}$ \\
\hline T1 & $680 \pm 225.153$ & $15.07 \pm 10.155$ & $11.72 \pm 6.413$ & $44.776 \pm 3.442$ \\
\hline T3 & $550 \pm 145.172$ & $19.12 \pm 11.066$ & $15.84 \pm 7.522$ & $41.273 \pm 3.860$ \\
\hline T4 & $435 \pm 208.597$ & $20.96 \pm 14.523$ & $15.06 \pm 6.658$ & $43.742 \pm 6.62$ \\
\hline T2 & $820 \pm 169.803$ & $16.38 \pm 9.559$ & $11.62 \pm 3.977$ & $45.111 \pm 3.340$ \\
\hline T6 & $685 \pm 95.782$ & $18.30 \pm 7.615$ & $9.65 \pm 3.463$ & $40.059 \pm 2.466$ \\
\hline T5 & $470 \pm 75.221$ & $19.14 \pm 15.552$ & $9.54 \pm 5.456$ & $40.392 \pm 8.104$ \\
\hline Mean & $606.67 \pm 147.230$ & $18.16 \pm 2.119$ & $12.24 \pm 2.667$ & $42.56 \pm 2.255$ \\
\hline
\end{tabular}


highest density was at transect $2\left(820 \pm 169.803\right.$ ind ha $\left.^{-1}\right)$, while the lowest density was at transect $5(470 \pm 75.221$ ind $\left.\mathrm{ha}^{-1}\right)$. The average diameter was $18.16 \pm 2.119 \mathrm{~cm}$. Transects 1 and 2 had the lowest stem diameter, while other transects had similar diameters. The height of trees averaged $12.24 \pm 2.667 \mathrm{~m}$ and basal area was $42.56 \pm 2.255 \mathrm{~m}$. Species with the highest diameter was A. marina $(85.35 \mathrm{~cm})$, while $R$. apiculata was the highest species $(27 \mathrm{~m})$. The average mangrove density in TANR was lower compared to the results derived from other studies [25,26]. However, diameter, height, and basal area of trees in TANR were similar. Low mangrove density illustrates that mangrove forests in TANR have experienced severe disruption. The remaining mangroves in that location are the undisturbed stand. Firman et al. [8] reported that there are eight villages around TANR with a population of 14,767 people, contributing to a serious threat to the existence of mangrove forests. Disturbance to mangrove forests in TANR is caused not only by the expansion of ponds but also by the development of settlements and plantations. Ponds have begun to receive greater attention since they are thought as the main contributor to mangrove depletion in Indonesia, including East Kalimantan [2, 6, 7].

The structure of mangrove vegetation in TANR differed among transects on the basis of composition and density of each individual. The Bray-Curtis similarity analysis revealed that there were two main groups of mangrove vegetation (Fig. 1). The structure of mangrove vegetation in TANR differed among transects on the basis of composition and density of each individual. The Bray-Curtis similarity analysis revealed that there were two main groups of mangrove vegetation (Fig. 1). The first group was transects 5 and 6 which had the highest similarity in terms of species composition. The prominent presence of $A$. marina and $S$. alba situated in the outer bay characterized the first group. Furthermore, the second group consisting of

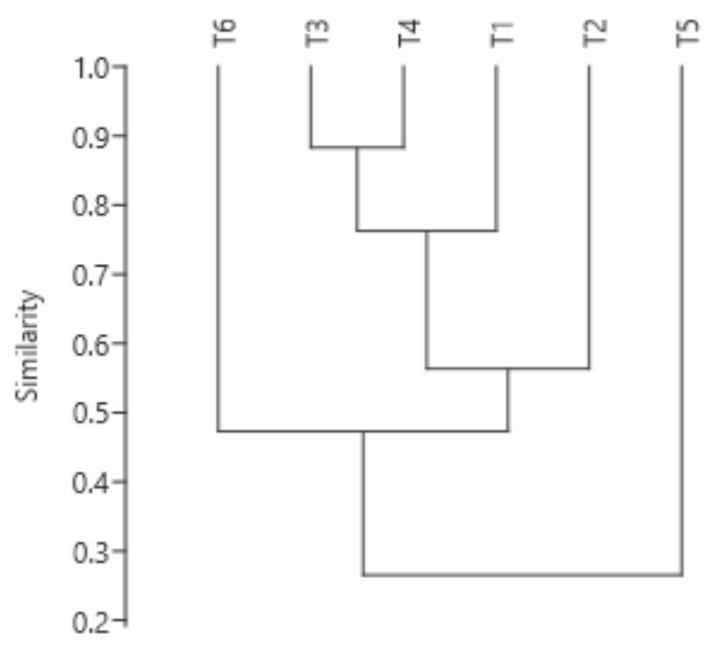

Fig. 1. Dendrogram analysis of similarities among transect locations based on species composition. transects $1,2,3$, and 4 was indicated by the abundance of $R$. apiculata and B. parviflora. The second group shared similarity of less than $50 \%$ with the first group. Unlike transects 5 and 6 , there were no A. marina and $S$. alba found at transects 1,2,3, and 4. Previous studies reported that $A$. marina and $S$. alba predominantly lived in areas close to the sea and were exposed to sunlight [27, 28, 29].

The IVI showed that $R$. apiculata had the highest score in all growth strata (Table 4): seedling 98.22\%, sapling $127.73 \%$, and tree $144.03 \%$. Another species with the high IVI in each strata was $B$. parviflora (seedling $18.69 \%$, sapling $68.50 \%$, and tree $61.30 \%$ ). $C$. tagal had the lowest IVI in the seedling strata (4.67\%), while $R$. mucronata had the lowest IVI in the sapling strata (12.14\%), and $X$. granatum had the lowest IVI in the tree strata $(3.15 \%)$.

$R$. apiculata is the most dominant mangrove species in TANR indicated by the highest IVI in all growth strata. The dominance of $R$. apiculata in mangrove in Southeast Asia had also been reported by numerous studies $[19,20,25,26,30]$. Rhizophora is the genus that has the most extensive distribution worldwide $[30,31]$. This genus has viviparous propagule and can float on water, so it can be widely distributed [30] . However, specifically, the $R$. mucronata is found to have the low IVI compared to $R$. apiculata. Shat et al. [25] explained $R$. apiculata will suppress $R$. mucronata growth if they are in the same habitat. Wah et al. [19] also reported that $R$. apiculata was very dominant in disturbed mangrove forests. In contrast, $R$. mucronata was dominant in undisturbed mangrove forests. This phenomenon also occurred in TANR. We found that $R$. apiculata could colonize the open areas of the former ponds that were no longer used.

$X$. granatum was mangrove species that had the lowest IVI in tree strata. In fact, individuals of this species were not recorded for seedlings. We also documented that there were no individuals of $S$. alba in the seedling strata. The absence of seedlings can be an indicator if the regeneration rate of these two species is very low. Failure to regeneration is a threat to the existence of a long-term plant species. Sidique et al. [32] explained that regeneration failure of $X$. granatum is strongly influenced by the level of water salinity. Salinity above 25 PSU (Practical Salinity Unit) is toxic to seeds, inhibits nutrient uptake and causes dying of seeds. S. alba can produce large amount of seeds [33, 34], but, most of the seeds die due to movement of sediments and sea waves [35]. Study by Alongi [36] in Kutai National Park found that there was a decrease in the survival rate of $S$. alba seedling up to $68.75 \%$ in just 3-month of observation period. Besides natural regeneration factors, it is noteworthy that $S$. alba is one of the favorite foods of proboscis monkey (Nasalis larvatus), a primate that has a strong association with mangrove forests. The high rate of consumption of leaves by the this primate makes $S$. alba dwarf and bald, and unable to produce seeds normally. 
Table 4. Important Value Index (IVI) of mangrove vegetation in TANR.

\begin{tabular}{|c|c|c|c|}
\hline Strata & No & Species & Important Value Index (\%) \\
\hline \multirow{7}{*}{ Seedling } & 1 & Rhizophora apiculata Blume & 98.22 \\
\hline & 2 & Avicennia marina (Forsk.) Vierh. & 58.07 \\
\hline & 3 & Bruguiera parviflora Wight \& Arn. & 18.69 \\
\hline & 4 & Rhizophora mucronata Lam. & 9.34 \\
\hline & 5 & Acrostichum aureum L. & 6.33 \\
\hline & 6 & Nypa fruticans Wurmb & 4.67 \\
\hline & 7 & Ceriops tagal (Perr.) C.B.Rob. & 4.67 \\
\hline \multirow{7}{*}{ Sapling } & 1 & Rhizophora apiculata Blume & 127.73 \\
\hline & 2 & Bruguiera parviflora Wight \& Arn. & 68.50 \\
\hline & 3 & Xylocarpus granatum Koening & 36.72 \\
\hline & 4 & Avicennia marina (Forsk.) Vierh. & 24.54 \\
\hline & 5 & Sonneratia alba J.E.Smith & 18.17 \\
\hline & 6 & Ceriops tagal (Perr.) C.B.Rob. & 12.19 \\
\hline & 7 & Rhizophora mucronata Lam. & 12.14 \\
\hline \multirow{7}{*}{ Tree } & 1 & Rhizophora apiculata Blume & 144.03 \\
\hline & 2 & Bruguiera parviflora Wight \& Arn. & 61.30 \\
\hline & 3 & Avicennia marina (Forsk.) Vierh. & 39.79 \\
\hline & 4 & Ceriops tagal (Perr.) C.B.Rob. & 34.50 \\
\hline & 5 & Sonneratia alba J.E.Smith & 12.30 \\
\hline & 6 & Rhizophora mucronata Lam. & 4.92 \\
\hline & 7 & Xylocarpus granatum Koening & 3.15 \\
\hline
\end{tabular}

Species Richness Index, Diversity Index, and Dominance Index

The variation in the species richness, diversity, and dominance indices in TANR was similar to the study conducted by Wah et al. [19] in Semporna Sabah and $\mathrm{Su}$ et al. [26] in Sarawak. It is reasonable as all studies took place in the same island. However, the Kruskal Wallis test showed that there was a significant difference $(\mathrm{P}<0.05)$ for each ecological index values

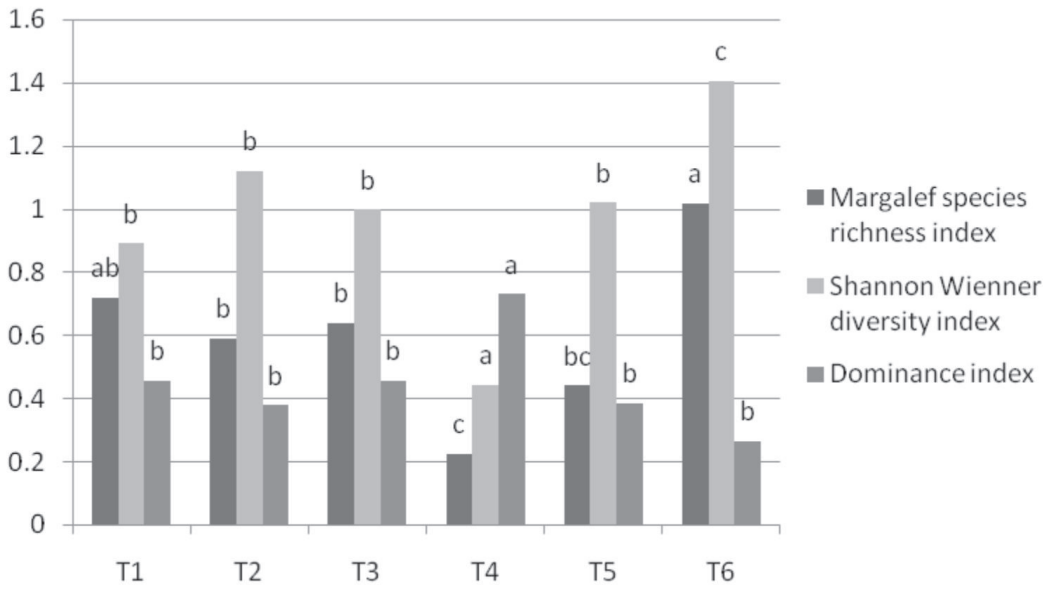

Fig. 2. Margalef species richness index, Shannon Wienner diversity index, and Dominance index of mangrove species in TANR. Different words in the bar chart marked significant differences at $\alpha=0.05 \%$. 
among transect locations. The Kruskal Wallis test showed that the Margalef richness index $\left(\mathrm{X}^{2}=7.410\right.$, $\mathrm{p}=0.006)$, the Shannon-Wienner diversity index $\left(\mathrm{X}^{2}=5.769, \mathrm{p}=0.016\right)$, and the dominance index $\left(\mathrm{X}^{2}=8.308, \mathrm{p}=0.003\right)$ were significantly differed among transects (Fig. 2). Different values of ecological indices can be attributed to differences in anthropogenic levels and environmental conditions of each transect. For instance, lowest values of Margalef richness and Shannon-Wienner diversity indices for transect 4 reflected the high anthropogenic pressure in the past due to the fish pond development. In contrast, the same indices for transect 6 was the highest since it was situated in the front zone of mangroves and received less anthropogenic pressures.

The TANR's geographical area is characterized by a large bay, so environmental condition differs among transects. Some transects with similar habitat characteristics are possible to have similar index values. Various environmental factors can lead to various composition, distribution, and density on each species. This indirectly influences species richness, diversity, and dominance indices. According to Saenger et al. [21] the mangrove species richness index in Kalimantan coastal region is strongly affected by environmental conditions that have higher evaporation and lower salinity compared to other regions in the world. In the long term, various research have predicted that climate change can also influence the adaptability of various mangroves species, influencing species richness index and diversity index [31, 37, 38].

\section{The Relationships between Species Density and Soil}

The CCA analysis revealed that the eigenvalues for the two main axes were 0.33444 and 0.18772 , respectively. The two axes could explain $91.98 \%$ of the variances of soil parameters in which each axis contributed to $58.91 \%$ (axis 1) and $33.07 \%$ (axis 2). Axis 1 had a strong correlation with various parameters, such as $\mathrm{pH}, \mathrm{N}, \mathrm{C}, \mathrm{C} / \mathrm{N}, \mathrm{Mg}, \mathrm{Na}, \mathrm{K}, \mathrm{CEC}$, and saturation. Meanwhile, for axis 2, only the saturation parameter had the strongest correlation. CCA analysis also produces a biplot ordination that illustrates the relationships between the transect location and soil conditions and also mangrove species and soil conditions (Fig. 3). Ordination of the biplot between the transect location and soil conditions showed that the transect 1,3 , and 4 had soil condition parameters with slightly high to high organic content ( $\mathrm{C}$ and $\mathrm{N}$ ), very high $\mathrm{Na}$ content, low $\mathrm{Ca}$ content, slightly high $\mathrm{Mg}$ content, medium $\mathrm{K}$ content, very high saturation, and the proportion of clay soils reached $29-36 \%$. Transect 2 and 5 were characterized by 1 soil condition parameter, which was a low $\mathrm{Ca}$ content. The soil $\mathrm{pH}$ of transect 6 was neutral, the $\mathrm{C} / \mathrm{N}$ was slightly high, and the proportion of sand texture reached $88.60 \%$. The relationships among density and distribution of mangrove species and the gradient of soil conditions had a high correlation value $(0.74)$ for axis 1 . The level of correlation among variables could be seen from the angle of the arrow, meaning the smaller the angle, the greater the correlation. This study identified that the density of $N$. fruticans, $S$. alba, and A. marina correlated with $\mathrm{C} / \mathrm{N}, \mathrm{pH}$, and the sandy soil texture. Meanwhile, the density of $R$. mucronata, B. parviflora, and $C$. tagal corresponded to Ca content and also the sandy soil texture. The density of $R$. apiculata and $A$. aureum had the strongest correlation with the silt and clay soil textures.

Differences in density and distribution of mangroves are influenced by various factors, such as geographic regions, tidals, precipitation, temperatures, salinity, soil types, and the levels of sun exposure [1-3, 28, 31].

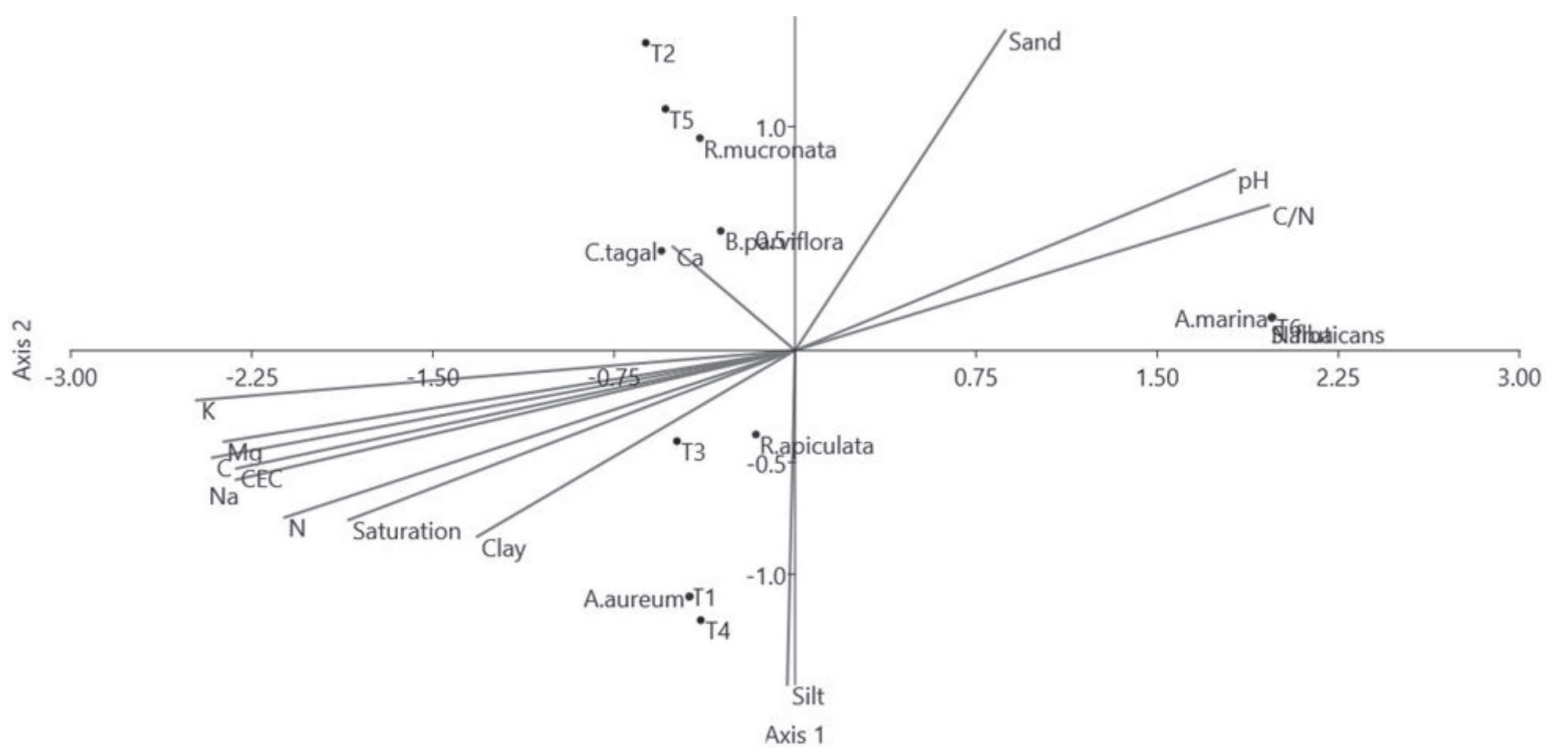

Fig. 3. CCA analysis biplot ordination of species density in TANR. The length of arrows explained the strength of correlation between soil properties and species density. The direction of arrows showed the pattern of correlation between soil properties and ordination axes. 
Soils in mangrove forests are alluvial mainly formed by sediment deposits originating from both rivers and the sea. The sandy soil texture found in transect 5 and 6 were affected by the position of the transects directly facing the outer bay. This condition had resulted in high influence of marine dynamics. A high proportion of the sandy soil texture in mangrove forests is from various marine biota, such as coral reef, mollusks, and echinoderms. The frequency of soil organic matter leaching through tidal mechanisms affected $\mathrm{pH}$ levels in transect 5 and 6 which had higher $\mathrm{pH}$ than others. The $\mathrm{pH}$ values in transects 5 and 6 were more neutral and almost the same as the $\mathrm{pH}$ conditions in the outer bay. The characteristics belonged to sandy soils finally led to special adaptation of certain mangrove species. For example, we only found A. marina and $S$. alba species around transect 5 and 6 . These species are known to inhabit mangrove typified by sandy soils $[35,38]$. Other species having a positive correlation with the proportion of the sandy soil are B. parviflora and $R$. mucronata. Both species primarily grow in the front zone of mangroves along with A. marina and $S$. alba.

The density and distribution of $R$. apiculata and A. aureum corresponded to the texture of clay and silt soils. $R$. apiculata had the highest density and the most extensive distribution in TANR. The difference in correlation of each species to the soil texture indicates the formation of mangrove forest zones. Soil conditions dominated by silt and clay textures are mostly inhabited by species grown in the middle to rear zones. A. aureum, for example, is one of mangrove associate species found in zones adjacent to terrestrial ecosystems. The correlation between mangrove species and soil conditions is similar to the results of previous studies revealing that $R$. apiculata favored silt and clay soil conditions $[39,40]$. The texture of clay and silt or mix of them is preferred by many mangrove species compared to the dominant sandy soil texture. Silt and clay soil textures tend to be darker, less porous, and the aeration and decomposition processes of organic matter run slower. Soil characteristics around the zone inhabited by $R$. apiculata and A. aureum have very high (C) and moderate (N) organic content. Organic materials originate from the primary productivity of the mangrove forests or the input from the outside of the mangrove ecosystem. Litter is organic matter derived from dead materials of mangrove plants. Several organic materials are from rivers and organic sediments from the sea.

C. tagal had association with low $\mathrm{Ca}$ content in the soil. This finding is similar to the results of study conducted by Sukardjo [41] in Teluk Apar Nature Reserve and Mukhlisi and Gunawan [35] in Kutai National Park. Low Ca content is related to soil organic matter leaching by tides. As a nutrient, $\mathrm{Ca}$ is useful to help the growth process of various mangrove species, including C. tagal. Ca content in soils is also useful to help reduce $\mathrm{Na}$ levels in the $C$. tagal tissue [42]. This mechanism benefits mangrove seedlings by reducing the toxic effects of high salinity. At high salinity levels, the effects of reduced $\mathrm{Na}$ content will appear on young plant parts, such as young shoots and leaves [42, 43].

\section{Conclusion}

To sum up, the mangrove forests in TANR were the remaining stand that had not been disturbed by human interventions. Based on the species composition, there were 9 new species found in TANR. Variations in species richness and diversity of mangrove were similar to other locations in Indonesia. However, some species were characterized by very low regeneration, thereby threatening their existence, especially $X$. granatum, $S$. alba, L. littorea, and C. decandra. As a conservation area, the degraded forest needs to be immediately restored to return its former state. Based on the national regulation, alternative ecosystem recovery techniques for conservation areas can refer to Permenhut No. P 48/Menhut-II/2014. Restoration efforts by planting mangrove species should consider the aspects of the suitability of sites based on zoning, seed availability, and the surrounding environmental conditions. Considering that most of the mangrove forests in TANR have been converted into fishponds, hence the restoration efforts require community involvement, and are carried out collaboratively through conservation partnership schemes. Furthermore, to maintain the remaining mangrove forests, environmental law enforcement is imperative.

\section{Acknowledgements}

We would like to thank and appreciate Priyono, Mursyid, Ashar Romadhona, and Ihsan for their help during data collection. This research was supported by PT. Kideco Jaya Agung, Natural Resources Conservation Agency of East Kalimantan (BKSDA Kalimantan Timur), and Research and Development Institute for Natural Resources Conservation Technology (Balitek KSDA)

\section{Conflict of Interest}

The authors declare no conflict of interest.

\section{References}

1. DUKE N.C., BALL M.C., ELLISON J.C. Factors influencing biodiversity and distributional gradients in mangroves. Global Ecol Biogeogr. 7, 27. 1998.

2. FAO. The World's Mangrove 1980-2005. Forest resources assesment working paper No.153. Food and Agriculture Organization of The United Nations. FAO: Rome, Italy, 2007 
3. REEF R., LOVELOCK C. Regulation of water balance in mangroves. Ann. Bot. 115, 385. 2015.

4. GIRI C., OCHIENG E., TIESZEN L.L., ZHU Z., SINGH A., LOVELAND T., MASEK J., DUKE N. Status and distribution of mangrove forests of the world using earth observation satellite data. Global Ecol Biogeogr. 20 (1), 154. 2011.

5. SPALDING M.D., KAINUMA M., COLLINS L. World Atlas of Mangroves. A collaborative project of ITTO, ISME, FAO, UNEP-WCMC, UNESCO-MAB, UNUINWEH and TNC: Earthscan, London, UK, 319. 2010.

6. THOMAS N., LUCAS R., BUNTING P., HARDY A., ROSENQVIST A., SIMARD M. Distribution and drivers of global mangrove forest change, 1996-2010. PLoS ONE. 12 (6), e0179302, 2017.

7. MEIJAARD E., NIJMAN V. Distribution and conservation of the proboscis monkey (Nasalis larvatus) in Kalimantan, Indonesia. Biol Conserv. 92, 15, 2000.

8. FIRMAN., RIZALI A., HIDYAT T. Model management of Adang Bay Nature Reserve in Invironmental conservation efforts in Paser Regency of East Kalimantan. Enviroscienteae. 13, 122, 2017.

9. BKSDA KALTIM. Inventory of flora in Teluk Adang Nature Reserve. BKSDA Kalimantan Timur: Samarinda, Indonesia. 67, 2015.

10. LEWIS III R.R. Ecologically based goal setting in mangrove forest and tidal marsh restoration. Ecol Eng. 15, 191, 2005.

11. PRIMAVERA J.H., ESTEBAN J.M.A. A review of mangrove rehabilitation in the Philippines: successes, failures and future prospects.Wetl Ecol Manag. 16 (5), 345, 2008.

12. GIRIRAJ A., MURTHY M.S,R, RAMESH B.R. Vegetation composition, structure and patterns of diversity: A case study from the tropical wet evergreen forest of the Western Ghats, India. Edinb. J Bot. 65, 447, 2008.

13. ENGLISH S., WILKINSON C., BAKER V. Survey manual for tropical marine resources. Australian Institute of Marine Science: Townsville Mail Centre, Australia. pp. 390, 1997.

14. SUKARDJO S. Natural regeneration status of commercial mangrove species (Rhizophora apiculata and Bruguiera gymnorrhiza) in the mangrove forest of Tanjung Bungin, Banyuasin, South Sumatra. Forest Ecol Manag. 20, 233, 1987.

15. MUELLER-DOMBOIS D., ELLENBERG H. Aims and Methods of Vegetation Ecology. John Wiley and Sons: New York, USA, 547, 1974.

16. BRAY J.R., CURTIS J.T. An ordination of the up-land forest assemblages of Southern Wisconsin. Ecol Monogr. 2 (7), 325, 1957

17. KRUSKAL W.H., WALLIS W.A. Use of ranks in onecriterion variance analysis. J Am Stat Assoc 260, 583, 1952

18. HAMMER Ø., HARPER D., RYAN P. PAST: Paleontological statistics software package for education and data analysis. Palaeontol Electron. 4, 1, 2001.

19. WAH L.M., MOJIOL A.R., SALEH E. Diversity of mangrove ecosystem in Semporna mangrove forest. Borneo Science. 28, 8, 2011.

20. POEDJIRAHAJOE E., SULISTYORINI I.S., KOMARA L.L. Species diversity of mangrove forest in Kutai National Park, East Kalimantan, Indonesia. Biodiversitas. 20 (12), 3641, 2019.

21. SAENGER P., RAGAVAN P., SHEUE C.R., LÓPEZPORTILLO J., YONG J.W.H., MAGESWARAN T.
Mangrove biogeography of the Indo-Pacific. In: GUL B., BÖER B., KHAN M., CLÜSENER-GODT M., HAMEED A. (eds) Sabkha Ecosystems. Tasks for Vegetation Science, Springer International Publishing: Switzerland, volume 49, 379, 2019.

22. GOMATHINAYAGAM M., ARUNPRASATH A. Growth performance of Ceriops decandra propagules as influenced by plant growth regulator: A conservation effort. J. Plant Stress Physiol. 1 (1), 1, 2015.

23. ELLISON J., KOEDAM N.E., WANG Y., PRIMAVERA J., JIN EONG O., WAN-HONG YONG J. NGOC NAM V.. Lumnitzera littorea. The IUCN Red List of Threatened Species 2010: e.T178854A7628170. 2010.

24. HIDAYAT T., KUSMANA C., TIRYANA T. Species composition and structure of secondary mangrove forest in Rawa Timur, Central Java, Indonesia. AACL Bioflux. 10 (4), 675, 2010.

25. SHAH K., KAMAL A.H.M., ROSLI Z., HAKEEM K.R., HOQUE M.M. Composition and diversity of plants in Sibuti mangrove forest, Sarawak, Malaysia. Forest Sci Technol. 12 (2), 70, 2016.

26. SU G., HUANG Y., FENGXIAO T., NI X., TANG T., SHI S. Conservation genetics of Lumnitzera littorea (Combretaceae), an endangered mangrove, from the IndoWest Pacific. Mar Biol. 150, 321, 2006.

27. THAMPANYA U., VERMAAT J.E., DUARTE C.M. Colonization success of common Thai mangrove species as function of shelter from water movement. Mar Ecol Prog Ser. 237, 111, 2002.

28. HANUM I.F., KUDUS K.A., SAARI N.S. Plant diversity and biomass of Marudu Bay Mangroves in Malaysia. Pak. J. Bot. 44 (1), 151, 2012

29. YUVARAJ E., DHARANIRAJAN K., JAYAKUMAR S., SARAVANAN., BALASUBRAMANIAM J. Distribution and zonation pattern of mangrove forest in Shoal Bay Creek, Andaman Islands, India. Indian J Geo Mar Sci. 46 (3), 597, 2017.

30. LO E.Y.Y., DUKE N.C., SUN M. Phylogeographic pattern of Rhizophora (Rhizophoraceae) reveals the importance of both vicariance and long-distance oceanic dispersal to modern mangrove distribution. BMC Evol Biol. 14, 83, 2014.

31. NUMBERE A., CAMILO G. Effect of temperature and precipitation on global mangrove Rhizophora species distribution. Am J Environ Sci 13 (5), 342, 2017.

32. SIDDIQUE M.R.H., SAHA S., SALEKIN S., MAHMOOD H. Salinity strongly drives the survival, growth, leaf demography, and nutrient partitioning in seedlings of Xylocarpus granatum J. König. iForest 10, 851, 2017.

33. WANG'ONDU V.W., KAIRO J.G., KINYAMARIO J.I., MWAURA F.B., BOSIRE J.O., GUEBAS F.D., KOEDAM $\mathrm{N}$. Vegetative and reproductive phenological traits of Rhizophora mucronata Lamk. and Sonneratia alba Smith. Flora. 208 (8), 522, 2013.

34. BALKE T., WEBB E.L., ELZEN E.V.D., GALLI D., HERMAN P.M.J., BOUMA T.J. Seedling establishment in a dynamic sedimentary environment: a conceptual framework using mangroves. J Appl Ecol. 50 (3), 740. 2013.

35. MUKHLISI, GUNAWAN W. Natural regeneration of mangrove seedlings in degraded area of Kutai National Park. JPK Wallaceae. 5 (2), 113, 2016.

36. ALONGI D.M. The impact of climate change on mangrove forests. Curr. Clim. Change Rep. 1 (1), 30, 2015.

37. WARD R.D., FRIESS D.A., DAY R.H., MACKENZIE R.A. Impacts of climate change on mangrove ecosystems: 
a region by region overview. Ecosyst Health Sust. 2 (4), e0121, 2016.

38. AMINUDDIN M., SUNARTO., PURNOMO D. Mangrove forest community structure in Eka Buana Village, East Lombok Regency, West Nusa Tenggara. AIP Conference Proceedings. 2120, 040019, 2019.

39. NUSANTARA M.A., HUTOMO M., PURNAMA H. Evaluation and planning of mangrove restoration programs in Sedari Village of Kerawang District, West Java: Contribution of PHE-ONWJ Coastal Development Programs. Procedia Environ Sci. 23, 207, 2015.

40. AMALIYAH S., HARIYANTO S., PURNOBASUKI H. 2017. Roots morphology of Rhizophora apiculata Blume as an adaptation strategy of waterlogging and sediment. $\mathbf{J}$ Biol Sci. 17, 118, 2017.

41. SUKARDJO S. Soils in the mangrove forests of the Apar Nature Reserve, Tanah Grogot, East Kalimantan, Indonesia. Southeast Asian Stud. 32 (3), 3851994.

42. AZIZ I., KHAN M.A. Experimental assessment of salinity tolerance of Ceriops tagal seedlings and saplingsfrom the Indus delta, Pakistan. Aquatic Botany. 70, 259, 2001.

43. NAVARRO J.F., BOTELLA M.A., CERDÁ A., MARTÍNEZ V. Effect of salinity $\times$ calcium interaction on cation balance in melon plants grown under two regimes of orthophosphate. J. Plant Nutr. 23 (7), 991, 2008. 